\title{
South African Journal of Military Science
}

\section{Editorial}

During the first half of 2021, and amidst the continuing throes to combat the global COVID-19 pandemic, there have been several notable developments that directly influenced global security and defence. Across the globe, countries have started vaccinating large segments of their populations against the COVID-19 virus in the hope of achieving population, or so-called 'herd immunity'. In developed countries, these processes have achieved some measures of success, with large numbers of people, including healthcare workers and persons at risk, receiving vaccinations in a timely manner. There has also been a gradual easing of rather stringent lockdown measures coupled with the introduction of these vaccinations. However, in developing countries, the situation regarding the introduction of vaccinations and the imposition of stringent lockdown measures remains problematic. Governments are struggling to obtain the necessary funds to procure the needed vaccinations on the global market, but these are often in short supply. The tardy introduction and administration of vaccinations further complicate matters. Moreover, when adding chronic mismanagement and corruption into the equation, along with a growing number of failed and ineffective states, the situation has - and will have - a distinct influence of human security across the globe. These issues will undoubtedly continue to develop over the course of the next few months.

Following the outcome of the 2020 United States presidential election, Joe Biden was inaugurated on 20 January 2021 as the $46^{\text {th }}$ president of the United States of America. Biden's election as president heralded in a new era for the United States, especially in terms of the realms of security and defence. Some of the most notable developments during Biden's first five months in office are his overtures to the North Atlantic Treaty Organisation (NATO) countries to rebuild trust, as well as his formal announcement that US troops will be fully withdrawn from Afghanistan by September 2021. In February 2021, while addressing the Munich Security Conference virtual event, Biden reaffirmed the commitment by the United States to the NATO alliance and the principle of collective defence - this, of course, being diametrically opposed to Donald Trump's 'America First' foreign policy. At the end of February, the United States and the Taliban had signed a peace agreement that would see the gradual withdrawal of all regular American 
troops from Afghanistan. In April, the Biden administration formally announced that they expect the withdrawal of troops to be completed by 11 September 2021, a decision that was mirrored by other NATO troop-contributing countries. The withdrawal of US troops in theory signals the end of a twenty-year-long deployment to Afghanistan that followed in the wake of the 9/11 attacks. However, while the withdrawal of US troops from Afghanistan is generally welcomed, it comes with several caveats. The withdrawal of US troops may leave a power vacuum within the country, which may see the collapse of the Afghan government that could result in a takeover by the Taliban. The worst case scenario would be the outbreak of a fresh Afghan civil war.

The rising Israeli-Palestinian tensions remain a cause for concern too, more especially following the outbreak of violence across Gaza and Israel in early May. The recent conflict, which has been marked by several indiscriminate attacks from both sides, occurs against the backdrop of mounting religious tensions and a recent court decision that would allow for the removal of Palestinian families from an East Jerusalem neighbourhood. The conflict, which has been marked by Hamas rocket attacks into Israel and retaliatory Israeli air strikes into Gaza, is gauged as the most violent since the so-called 'Gaza War' of 2014.

In southern Africa, the escalating conflict in the resource-rich northern province of Cabo Delgado in Mozambique between government forces and a local armed group linked to the Islamic State of Iraq and the Levant (ISIL) remains a cause for concern in terms of defence and continued security across the region. The inability of the Mozambican government to deal effectively with the insurgency in Cabo Delgado, coupled with the withdrawal of several multinational companies from the region, the use of South African mercenaries, and the recent attack on Palma, has prompted the Southern African Development Community (SADC) to reassess the security situation. This resulted in the recent SADC fact-finding mission to Mozambique to assess the situation on the ground and to decide on an appropriate regional response to the insurgency. This occurred against the backdrop of continuing pleas from Mozambique for foreign intervention to help curb the violence in Cabo Delgado. We might therefore soon see the operational deployment of SADC troops to the ungoverned space of northern Mozambique to combat the Islamist insurgents. This will of course include the deployment of the already over-stretched - and critically underfunded - South African National Defence Force (SANDF). Such a deployment will definitely test the manpower, operational capabilities and doctrine of the SANDF, who for the past twenty years or so have been involved mainly in peacekeeping missions in Africa - principally in Burundi, the Democratic Republic of the Congo and Darfur in Western Sudan. South Africans in particular will closely monitor the situation in Cabo Delgado as it develops over the coming months.

In this issue of Scientia Militaria, Vol. 49, No. 1, 2021, the articles consider both historic and contemporary issues related to war and conflict, as well as defence and security-related matters. As always, it is hoped that these articles will provide key insights and act as a source of influence for individuals involved in the broader ambit of military planning, operations, management and higher education. 
In his article on the South African security predicament, Abel Esterhuyse considers the key features of the South African security agenda. Historically, this security agenda has been influenced by the unique South African threat perception, which, irrespective of the ruling entity of the day, focused on security threats emanating from outside Africa, security threats facing the country from within Africa, and security threats prevalent within the borders of the country. Esterhuyse also reflects on the ability of the human security paradigm to address the unique South African security predicament, specifically against the backdrop of the domestic and regional security agenda.

Charles van Wijk and Jarred Martin propose a new approach in their article for enhancing psychological adaptation among South African Navy sailors. They argue that the mission of the Institute for Maritime Medicine is to support and enhance the operational performance of South African Navy sailors during maritime operations, while also ensuring positive long-term mental health outcomes of sailors. In order to achieve this, Van Wijk and Martin propose that the mobilisation and/or demobilisation programmes used for ship-based maritime operations need to be reoriented towards a predict-and-promote approach. According to them, such an approach will enhance the psychological adaptation of sailors to the emotional demands of deployment as well as support more adaptive forms of mental health resilience, both before and after sea-going operations.

The article by Eben Coetzee reflects on hypersonic weapons and the future of nuclear deterrence. The development of hypersonic weapons provides unprecedented advantages in warfare in terms of the speed and agility of the missiles. The increase in the speed and agility of hypersonic missiles further drastically reduces the response time of nuclear states in the event of attack, and therefore encourages the pre-emptive use of force. Coetzee also argues that the speed and agility of hypersonic missiles are likely to render existing and future missile defences obsolete. This will lead to a situation where the failure of missile defences, coupled with a reduction in the response time of nuclear states to such attacks, in fact encourages the pre-emptive use of force. Where nuclear states are unable to field survivable second-strike forces, the stability of nuclear deterrence becomes highly problematic. Coetzee also considers the challenges, if any, which hypersonic weapons pose for the militaries of technologically less-advanced states, particularly those that primarily rely on conventional (non-nuclear) means to fend off aggressors.

In his article on the Battle of Hornkranz that took place in 1893, Piet van Rooyen reports on an overlooked event in the broader Namibian struggle for liberation. He argues that the liberation of Namibia is traditionally equated to the more recent struggle of the South West African People's Organisation, instead of against a bigger historical backdrop of anti-colonial resistance. Van Rooyen maintains that contemporary historians habitually overlook the brutal era of German colonisation when they write about the struggle for Namibian liberation. He argues that the Namibian struggle for liberation lasted nearly a century, and started for example with the battle that occurred between the Witboois and Germans at Hornkranz in April 1893. 
In their article, James Jacobs and Johan Wassermann consider the South African War College military history staff ride as an education and training method related to the curriculum of the Senior Staff programmes presented at the college since 2002. They argue that the education and training process at the college, with specific reference to the staff ride to military battle sites and the associated application of the theory of operational art, was researched according to the tenets of the theory of deep learning. Jacobs and Wassermann further contend that, while it is possible to claim some deep learning successes using the military history staff ride, continuous reflection and educational interventions are needed to maintain the successes achieved and to use these as a building platform for deep learning during future military history staff rides.

In the final article, Andreas Biermann presents a reassessment of the tank battle that occurred between the British Fourth Armoured Brigade and German Panzerregiment 5 during Operation Crusader in North Africa on 19 November 1941. By utilising primary documents, such as war diaries, messages and reports, Biermann provides a new perspective on the established view of the battle. He further reassesses the comparative tank combat performance in the early phase of Operation Crusader by analysing the first engagement between Allied and German armour with a view to correcting the misconceptions that have clouded the historical record until now. By using primary archival material, Biermann sheds new light on the losses in tanks suffered by both sides during the battle and considers how the opposing forces performed in the context of their operational objectives.

A selection of several contemporary published works reviewed by Jean-Pierre Scherman, Abel Esterhuyse, David Katz, Anri Delport and Evert Kleynhans concludes this issue of Scientia Militaria.

\section{The Editor \\ Evert Kleynhans}

